\title{
Awareness of Occupational Diseases in Training Internal Medicine: The Importance of Continuing Education
}

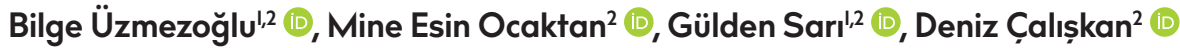 \\ 'Department of Occupational Medicine, Atatürk Chest Diseases and Thoracic Surgery Training and Research Hospital, Ankara, Turkey \\ 2Department of Public Health, Ankara University School of Medicine, Ankara, Turkey
}

ORCID IDs of the authors: B.Ü. 0000-0002-9398-5I73; M.E.O. 0000-000I-7576-4943; G.S. 0000-0003-I098-4405; D.C̣. 0000-0002-48770122.

Cite this article as: Üzmezoğlu B, Ocaktan ME, Sarı G, Çalıșkan D. Awareness of Occupational Diseases in Training Internal Medicine: The Importance of Continuing Education. Cyprus J Med Sci 2019; 4(I): 5-13.

\section{BACKGROUND/AIMS}

Diagnosis of occupational diseases (ODs) by physicians is one of the most important steps in protecting the health of employees. The aim of the present study was to evaluate the awareness of residents who were training in the internal medicine disciplines on OD.

\section{MATERIAL and METHODS}

This was a cross-sectional study. The survey based on self-declaration was administered to first-year and last-year residents training in the internal medicine disciplines of a medical faculty in Ankara University School of Medicine. There was no valid survey used for the assessment of knowledge and awareness of physicians in diagnosing OD. The survey was created by utilizing the questions used in some similar studies and professional experiences of the researchers.

\section{RESULTS}

Of a total of 139 physicians, $57.6 \%$ stated that they had pregraduate OD training, and $19.3 \%$ stated that they had postgraduate OD training Among the first-year and last-year research assistants, those who expressed that "they questioned occupations while evaluating their patients" were $34.3 \%$ and $36.8 \%$ of the participants, respectively. With regard to the primary approaches of research assistants upon confronting with rarely occurring complaints and findings, $8.7 \%$ of first-year residents and $24.6 \%$ of last-year residents stated that "they questioned the patient about environmental and occupational exposure."

\section{CONCLUSION}

Our study results indicate that training on ODs during residency and physicians' knowledge and awareness about the methods used in diagnosis, legal aspects, and notification procedures regarding ODs need to be improved and should be developed in their continuing education.

Keywords: Awareness, continuing education, occupational diseases, physicians

\section{INTRODUCTION}

According to the International Labor Organization (ILO), 160 million new occupational disease (OD) cases are expected annually, and 10\% result in permanent or long-term disability (I). In general, ODs are slowly progressing diseases. The disease may occur even years after leaving the job. It has signs and symptoms that can be seen in many diseases. Therefore, it is important to establish the causal relationship between disease and occupational exposure. It is necessary to take a detailed history about the occupation of each patient to prevent misdiagnosis, process of job in which she/he works, work environment, period of employment and exposures, and intensity of exposures. Taking appropriate and adequate occupational history allows the physician to make correct and early diagnosis, to plan the correct treatment, and to conduct preventive studies in the workplace with the assessment of other employees (2). In addition, detecting OD in a workplace proves that occupational risks are not managed adequately by the employer (3). Therefore, physicians play an important role in the improvement of occupational health and prevention of ODs (2).

The institutions responsible for making the medical diagnosis of ODs in Turkey include hospitals, training and research hospitals of the Ministry of Health, and public university hospitals. Upon diagnosis of an OD, it is obligatory to notify the 
relevant authorities. This is because OD has legal consequences as well. This diagnosis brings about some compensation rights to the employee. The legal diagnosis of OD is made by the Social Security Institution (SSI) in Turkey. In short, the diagnosis of OD and notification of relevant authorities are associated with a series of medicolegal responsibilities. When physicians diagnosed $O D$, they contribute to the accurate analysis of data regarding occupational health and aid the government in developing the necessary measures about occupational health and safety indirectly. The level of training, knowledge, and awareness of the physicians on OD determines the diagnosis.

The aim of the present study was to evaluate the level of knowledge and awareness of research assistants who were training in the internal medicine disciplines of a public medical faculty hospital in Ankara University School of Medicine to diagnose OD.

\section{MATERIAL and METHODS}

This was a cross-sectional design study and was conducted between March I, 2017, and April 30, 2017.

\section{Study Population and Sample}

The study population comprised first- and last-year research assistants ( $n=278$ ) working in 20 internal medicine disciplines of the medical faculty of Ankara University during 2016-2017.
The study sample included 139 physicians after exclusion of those who could not be reached due to pregnancy or maternity leave, annual leave, sick leave, external rotation, out-of-hospital assignment, and those who did not attend due to their excess workload. The reason for selecting the disciplines of internal medicine was that they were the departments in which the diagnoses of ODs and work-related diseases were encountered much often compared with surgical disciplines. Since the medical faculty hospital serves multiple campuses, there were some difficulties in reaching research assistants collectively.

The minimum sample volume and strength analysis of the study were calculated by two independent proportions (null case) power analysis. The study was approved by the ethics committee of Ankara University, Medical Faculty (Decision date: 02/23/2017; No.: 20 96487027-044-E.5469).

\section{Data Collection}

Data were obtained with a survey form applied to the participants. Days and hours with lower patient-load in the outpatient clinics, including lecture hours, non-visit hours, and hours with lesser workload in the in-patient clinics, were chosen for data collection to increase participation. All participants were informed about the purpose of the study. Written informed consent was obtained from the participants.

TABLE I. Distribution of some demographic characteristics of the participants according to their years in residency training*

Characteristics

\begin{tabular}{ll}
\multicolumn{2}{c}{ First year } \\
\hline n $\quad \%$
\end{tabular}

Gender ( $n=139)$

Female

Male

Place of graduation $(n=138)$

Medical faculty inside Ankara

Medical faculty outside Ankara

Foreign medical faculty

Medical faculty graduated in Ankara ( $n=72)$

Ankara University, Medical Faculty

Hacettepe University, Medical Faculty

Gazi University, Medical Faculty

Private University, Medical Faculty

Occupational diseases training status before graduation $(n=139)$

Trained

Untrained

Occupational diseases training status after graduation $(n=138)$

Trained

Untrained

Occupational diseases training status during residency $(n=133)$

Trained

Untrained

*Column percentage was estimated over responders, $p<0.05$

\section{4}

26

37

29

3

16

13

5

3

14

62.9
37.1

Year of residency training

Year of residency training

\begin{tabular}{ll}
\multicolumn{2}{c}{ Last year } \\
\hline $\mathrm{n}$ & $\%$
\end{tabular}

\begin{tabular}{ll}
\multicolumn{3}{c}{ Total } \\
\hline$n$ & $\%$
\end{tabular}

n

42
27

60.9

86

61.9

P

$+$

\section{*}




\section{Data Collection Tools}

Since there was no nationally or internationally valid scale for assessment of physicians' knowledge and awareness about $O D$, a questionnaire was created by utilizing the questions used in some similar studies and professional experiences of the researchers anonymously. The questionnaire consists of four sections: general information, awareness assessment, knowledge level, and free section.

\section{Pilot Study}

The pilot study in which the quality of questions and the duration of filling were evaluated was performed with second-year and three-year research assistants in the internal medicine disciplines of the medical faculty of Ankara University.

\section{Statistical Analysis}

The Statistical Package for the Social Sciences for Windows version 15.0 (SPSS Inc., Chicago, IL, USA) was used to calculate the chi-square test. Descriptive categorical data were expressed

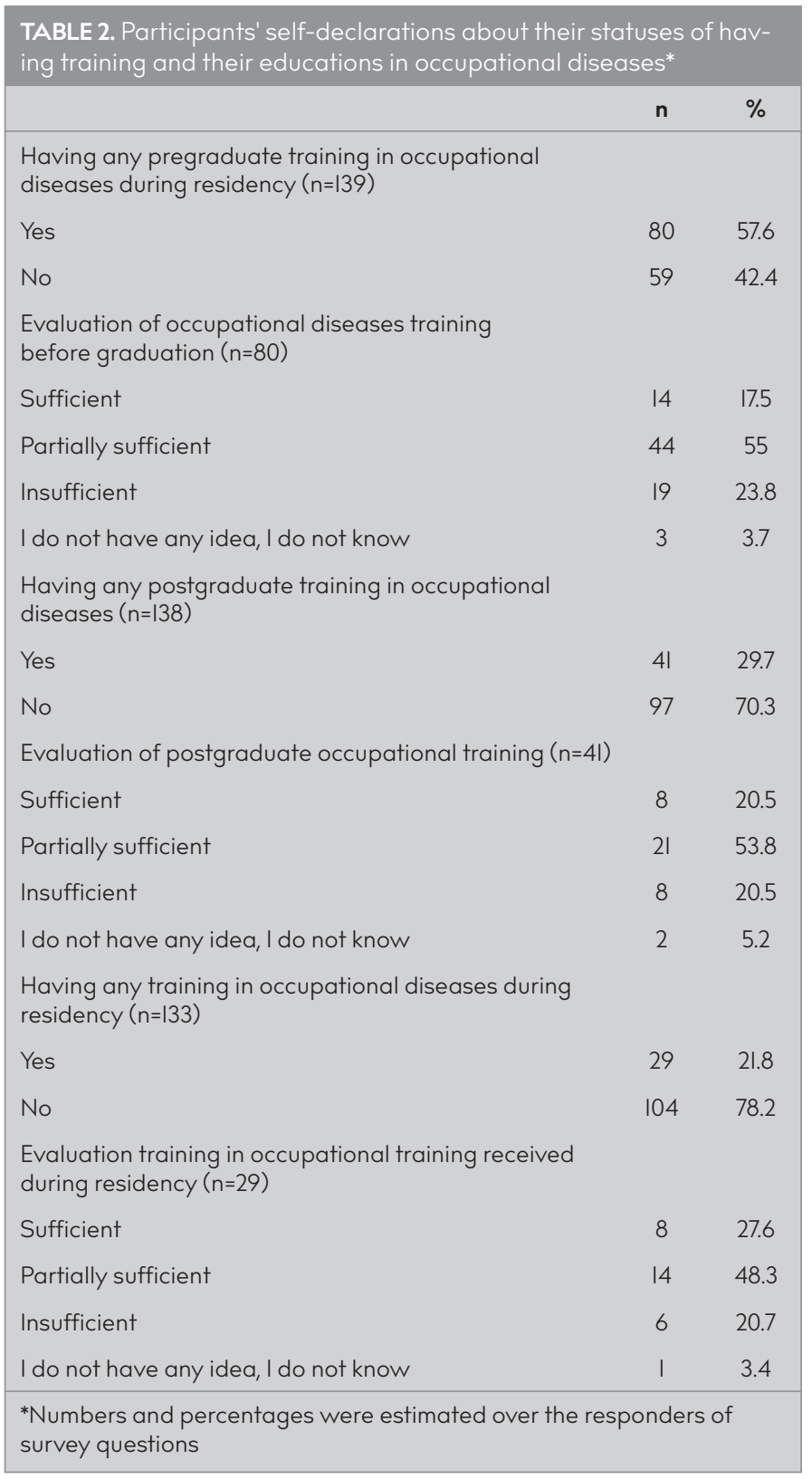

as count and percentage, whereas continuous data were expressed as mean and standard deviation. The chi-square test was used for comparison of categorical data. A p value of $<0.05$ was accepted as statistically significant.

\section{RESULTS}

\section{Demographic Characteristics of Participants}

The mean age of the 139 participants working in the internal medicine disciplines as first-year $(n=70)$ and last-year $(n=69)$ research assistants was $28.65 \pm 3.26$ (range: $24-41$ ) years, and the mean duration of employment was $4.75 \pm 2.9$ ( Table I shows the descriptive characteristics of participants according to residency years. Of the 139 participants, $61.9 \%$ were female. There was no statistically significant difference when the residency year was compared with the medical faculties they had graduated ( $p=0.668$ ). Physicians who attended to the study were from 20 different residency training departments, and most were training on internal medicine (28.8\%).

\section{Training of Participants on OD}

Among all 139 participants, 57.6\% had training in ODs during their medical faculty education, whereas $55 \%$ had evaluated this training as "partially sufficient." Participants who had training on OD during their residencies were low $[n=29(21.8 \%)]$ and evaluated their education as "partially sufficient" (48\%) (Table 2).

\section{Awareness of Taking Occupational History}

Physicians who asked patients their professions "always definitely" while taking medical history were low (35.5\% of the total participants). Of the 139 participants, $28.3 \%$ are informed "rare$\mathrm{ly} /$ never" asked their professions. With regard to the attitudes about taking medical histories aimed at occupational and environmental exposures, those who stated that they "rarely/never" obtained medical history about occupational and environmental exposures were greater in number $(n=79$ (56.8\%) and $n=86$ (62.3\%), respectively). The majority of participants did not ask patients about their previous jobs. The majority of first-year and last-year residents stated that they "rarely/never" questioned their patients about their occupational and environmental exposures (Table 3). With regard to taking occupational history, $36 \%$ of the participants stated that they only asked the last job of their patients, whereas $27.9 \%$ asked in a short manner, such as worker, civil servant, retired, or housewife. The rate of participants taking occupational history according to chronological order was found to be $14.7 \%$. Although no statistical significance was found, it was observed that physicians' attitude of inquiring, such as civil servants, workers, retired, and housewives, decreased as the number of working years and their seniorities in residency increased (Table 4).

With regard to the methods used for accessing the diagnosis generally in the daily practice, the attitudes of applying for further laboratory and radiological investigations and searching for the diagnosis through the scientific websites over the internet were higher. On the other hand, the attitudes of asking the patient's environmental and occupational exposures were in the third or fourth place (Table 5). Nevertheless, while physicians' years of seniority increased, it was observed that the number of physicians questioning occupational and environmental exposures is increased (Table 5). 


\section{Participants' Awareness of ODs}

The participating physicians evaluated their knowledge level about the International Statistical Classification of Diseases system of ODs, ILO list of ODs, notification of ODs, legal aspect of ODs, and access to basic information sources about the

TABLE 3. Asking questions about occupational and environmental exposures by the participants in their medical practices*

\begin{tabular}{|lccc|}
$\begin{array}{l}\text { Frequency of the questions asked related } \\
\text { to the occupations of patients during } \\
\text { patient examination in daily practice }\end{array}$ & $\begin{array}{c}\text { First-year } \\
\text { assistant }\end{array}$ & $\begin{array}{c}\text { Last-year } \\
\text { assistant }\end{array}$ \\
\hline & $\mathbf{n}(\%)$ & $\mathbf{n}(\%)$ & p* \\
\hline $\begin{array}{l}\text { Questioning occupation } \\
\text { Always definitely }\end{array}$ & $24(34.3)$ & $25(36.8)$ & 0.700 \\
Sometimes & $24(34.3)$ & $26(38.2)$ \\
Rarely/never & $22(31.4)$ & $17(25.0)$ &
\end{tabular}

Taking medical history encompassing the occupations performed before

$\begin{array}{lccl}\text { Always definitely } & 7(10.0) & 12(17.4) & 0.374 \\ \text { Sometimes } & 21(30.0) & 22(31.9) & \\ \text { Rarely/never } & 42(60.0) & 35(50.7) & \\ \text { Questioning occupational exposure } & & & \\ \text { Always definitely } & 4(5.7) & 8(11.6) & 0.467 \\ \text { Sometimes } & 25(35.7) & 23(33.3) \\ \text { Rarely/never } & 41(58.6) & 38(55.1)\end{array}$

Whether $\mathrm{s} /$ he has a work-related disease or not, asking occupational exposure

\begin{tabular}{|c|c|c|}
\hline Always definitely & $8(I I .4)$ & II (I5.0) \\
\hline Sometimes & 31 (44.3) & $21(30.4)$ \\
\hline Rarely/never & $3 \mid(44.3)$ & $37(53.6)$ \\
\hline
\end{tabular}

Asking/evaluating the opinion of the patient with respect to whether there is a relationship between her/his disease and occupation

\begin{tabular}{|c|c|c|c|}
\hline Always definitely & $7(10.0)$ & $4(5.8)$ & 0.436 \\
\hline Sometimes & $24(37.1)$ & $32(46.4)$ & \\
\hline Rarely/never & $37(52.9)$ & $33(47.8)$ & \\
\hline \multicolumn{4}{|c|}{ Asking non-occupational environmental exposure } \\
\hline Always definitely & $5(7.1)$ & $9(13.2)$ & 0.465 \\
\hline Sometimes & $19(27.1)$ & $19(27.9)$ & \\
\hline Rarely/never & $46(65.7)$ & $40(58.8)$ & \\
\hline \multicolumn{4}{|c|}{ Asking environmental exposure } \\
\hline Always definitely & $7(10.0)$ & $9(13.0)$ & 0.844 \\
\hline Sometimes & $25(35.7)$ & $23(33.3)$ & \\
\hline Rarely/never & $38(54.3)$ & $37(53.6)$ & \\
\hline
\end{tabular}

Asking/evaluating the opinion of the patient with respect to whether there is a relationship between her/his disease and non-occupational environment

\begin{tabular}{|c|c|c|}
\hline Always definitely & $6(8.6)$ & $5(7.2)$ \\
\hline Sometimes & $20(28.6)$ & $21(30.4)$ \\
\hline Rarely/never & $44(62.9)$ & $43(62.3)$ \\
\hline
\end{tabular}

${ }^{*}$ Column percentages over the responses given. There was no statistically significant difference among the groups of all participants in the evaluation of the responses to the questions, $p<0.05$ issue as "insufficient." They considered their knowledge level about the diagnosis, treatment, social aspect, and prevention of ODs as "partially sufficient," and there was no statistically significant difference between the two groups (Table 6). There was no difference among the groups when self-declarations about knowledge level were compared according to whether they had pre-graduate and postgraduate training in ODs or according to their years in residency. The percentage of physicians who reported that OD was almost completely preventable was $87.1 \%$.

Most of the participants reported that the specialty that was most concerned about ODs was pulmonary medicine (61.8\%). Of the 139 participants, $26.6 \%$ stated that pneumoconiosis and contact dermatitis were the most commonly diagnosed ODs in Ankara University School of Medicine (Figure I). Of those, $35.9 \%$ stated that the most common OD worldwide was "work-related stress," ranking in the first place. This was followed by contact dermatitis in the second place with $28 \%$ (Figure 2).

With regard to the physicians' knowledge about the institutions authorized to diagnose ODs and about the fact that SSI is responsible for the legal diagnosis of OD, the majority of physicians did not know these two legislations correctly. There was

TABLE 4. Comparison of some characteristics of the participants
with respect to making the diagnosis of occupational disease*
$\begin{array}{lcc}\text { First-year } & \text { Last-year } \\ \text { Some characteristics } & \text { assistant } & \text { assistant } \\ \text { of diagnostic process } & \mathbf{n}(\%) & \mathbf{n}(\%)\end{array}$ p*

Whether the medical history form includes the section inquiring the occupation of the patient or not

Present

$38(55.1)$

$32(47.1) \quad 0.634$

Absent

$23(33.3) \quad 26(38.2)$

$\mathrm{S} /$ he does not know

$8(11.6)$

$10(14.7)$

How the occupation of the patient is asked generally while taking medical history

Those who ask only the last

occupation s/he is working

$23(33.3) \quad 26(38.8) \quad 0.554$

Those who ask the occupation

and exposure of each patient

in chronological order $9(13.0) \quad$ II (16.4)

I only ask the lines of work

$2(2.9) \quad 3(4.5)$

Those who make the inquiry, such as civil servant, retired, and housewife

$23(33.3) \quad 15(22.4)$

Those who do not make inquiry

$10(14.5) \quad 7(10.4)$

Others

2(2.9)

$5(7.5)$

Follow-up of cases in which occupational disease was detected during residency

$\begin{array}{lrrr}\text { Yes } & 13(18.8) & 21 & 0.114 \\ \text { No } & 56(81.2) & 48(69.6) & \\ \text { Making the diagnosis of occupational disease related to his/her } & \\ \text { specialty during residency up to today } & & & \\ \text { Yes } & 7(10.3) & 19(27.5) & 0.010 \\ \text { No } & 61(89.7) & 50(72.5) & \\ \text { *Column percentages of the responses given, } \mathrm{p}<0.05 & \end{array}$

*Column percentages of the responses given, $p<0.05$ 
TABLE 5. Comparisons of approaches to reaching the diagnosis depending on the year of residency in the daily practice of research assistants*

Cases

Method of reaching the diagnosis

Requesting further laboratory and radiological investigations

Doing research on the internet through scientific websites

Initiating empirical therapy and reaching the diagnosis through treatment occupational exposures of the patient

\section{Primary approach when rare complaints and findings are} encountered
Primary approach to the case who cannot be diagnosed despite the investigations performed

\section{Approach to the patient}

unresponsive to primary treatment appropriate treatment

First year $n_{1}(\%)$
Last year $n_{2}(\%)$

$17(24.6)$

21 (30.4)

First year $n_{1}(\%)$

26 (37.7)

Last year $n_{2}(\%)$

$16(23.2)$

First year $n_{1}(\%)$

$14(20.3)$

Last year $n_{2}(\%)$

$10(14.5)$

First year $n_{1}(\%)$

$6(7.6)$

$5(7.2)$

$6(8.7)$

$17(24.6)$

Last year $n_{2}(\%)$

$$
\begin{aligned}
& 4(5.8) \\
& 3(4.3) \\
& 33(47.8) \\
& 25(36.2) \\
& 5(7.2) \\
& 6(8.7) \\
& 18(26.1) \\
& 22(31.9) \\
& 9(13)
\end{aligned}
$$

$26(37.7)$

$29(42)$

$25(36.2)$

$18(26.1)$

$2(2.9)$

$3(4.3)$

$12(17.4)$

II (15.9)

$4(5.8)$

$8(I 1.6)$
30 (43.5)

$39(56.5)$

$13(18.8)$

$8(11.6)$

$3(4.3)$

$3(4.3)$

$14(20.3)$

$4(5.8)$

$9(13.0)$

$15(21.7)$

$\mathrm{n}_{1}$ : First-year research assistant, $\mathrm{n} 2$ : Last-year research assistant

${ }^{*}$ Column percentages over the responses given

TABLE 6. Comparison of the participants' self-assessment related to their knowledge of occupational diseases*

\section{Self-assessment of

\begin{tabular}{|c|c|c|c|}
\hline \multicolumn{4}{|c|}{ Protection against occupational diseases } \\
\hline Sufficient & $6(9.0)$ & $7(10.3)$ & \multirow[t]{3}{*}{0.115} \\
\hline Partially sufficient & $44(65.7)$ & $33(48.5)$ & \\
\hline Insufficient & $17(25.4)$ & $28(41.2)$ & \\
\hline \multicolumn{4}{|c|}{$\begin{array}{l}\text { Whether the subspecialty program of your specialty contains } \\
\text { occupational diseases or not }\end{array}$} \\
\hline Sufficient & $16(23.5)$ & $20(29.9)$ & \multirow[t]{3}{*}{0.407} \\
\hline Partially sufficient & $20(29.4)$ & $14(20.8)$ & \\
\hline Insufficient & $32(47.1)$ & $33(49.3)$ & \\
\hline \multicolumn{4}{|c|}{$\begin{array}{l}\text { Access of your specialty to basic information sources related to } \\
\text { occupational diseases }\end{array}$} \\
\hline Sufficient & $9(13.4)$ & $11(16.2)$ & \multirow[t]{3}{*}{0.303} \\
\hline Partially sufficient & $25(37.3)$ & $17(25.0)$ & \\
\hline Insufficient & $33(49.3)$ & $40(58.8)$ & \\
\hline \multicolumn{4}{|c|}{ Legal aspect of occupational diseases } \\
\hline Sufficient & $3(4.4)$ & $5(7.4)$ & \multirow[t]{3}{*}{0.263} \\
\hline Partially sufficient & $24(35.3)$ & $16(23.5)$ & \\
\hline Insufficient & $4 \mathrm{l}(60.3)$ & $47(69.1)$ & \\
\hline \multicolumn{4}{|c|}{ Social aspect of occupational diseases } \\
\hline Sufficient & $7(10.3)$ & $5(7.6)$ & \multirow[t]{3}{*}{0.845} \\
\hline Partially sufficient & $31(45.6)$ & $32(48.5)$ & \\
\hline Insufficient & $30(44.1)$ & $29(43.9)$ & \\
\hline
\end{tabular} \\ their knowledge related \\ to the diagnosis, treatment, \\ and notification of \\ occupational diseases}

$\begin{array}{lccc} & \mathbf{n}(\%) & \mathbf{n}(\%) & \mathbf{p}^{*} \\ \text { Notification of occupational diseases } & & & \\ \text { Sufficient } & 2(2.9) & \text { I(1.5) } & 0.267 \\ \text { Partially sufficient } & 33(47.8) & 24(35.3) & \\ \text { Insufficient } & 34(49.3) & 43(63.2) & \end{array}$

International Statistical Classification of Diseases code list of your specialty's occupational diseases

$\begin{array}{lccl}\text { Sufficient } & 3(4.3) & 5(7.2) & 0.427 \\ \text { Partially sufficient } & 24(34.8) & 17(24.6) & \\ \text { Insufficient } & 42(60.9) & 47(68.1) & \\ \text { ILO list of occupational diseases } & & & \\ \text { Sufficient } & 1(1.5) & 6(8.8) & 0.102 \\ \text { Partially sufficient } & 23(34.3) & 17(25.0) & \\ \text { Insufficient } & 43(64.2) & 45(66.2) & \\ \text { Diagnosis of occupational diseases } & & & \\ \text { Sufficient } & 5(7.4) & 3(4.4) & 0.126 \\ \text { Partially sufficient } & 45(66.2) & 36(52.2) & \\ \text { Insufficient } & 18(26.5) & 30(43.5) & \\ \text { Treatment of occupational diseases } & & & \\ \text { Sufficient } & 4(5.9) & 3(4.4) & 0.300 \\ \text { Partially sufficient } & 37(54.4) & 29(42.6) & \\ \text { Insufficient } & 27(39.7) & 36(53.0) & \end{array}$

no statistical difference in the comparison of this knowledge among the groups (Table 7).

The rate of physicians who knew the fact that making the diagnosis of an OD correctly might have protected the physician against malpractice was $71.9 \%$. 


\section{General Opinions, Concepts, and Suggestions}

Common responses given to the open-ended questions were categorized by a biostatistician, and variables were compared.

When their "opinions about work-related diseases" were asked, 27 out of 46 responders considered that the subject was not well known, and that the awareness of it was insufficient.

The answers given by 50 doctors to the question "What are the difficulties you have experienced in the process of diagnosis, treatment, and notification of OD related to your specialty?" were categorized. Seven doctors stated that they did not have any knowledge, four doctors stated that OD did not come to their mind while examining their patients, and eight research assistants reported that they did not see enough patients about this issue. Eighteen doctors reported that they had lack

TABLE 7. Participants' knowledge of some issues related to the legal process and frequency of occupational diseases*

\begin{tabular}{|c|c|c|c|}
\hline $\begin{array}{l}\text { Legal process and } \\
\text { frequently related } \\
\text { questions }\end{array}$ & $\begin{array}{c}\text { First-year } \\
\text { assistant } \\
\mathrm{n}(\%)\end{array}$ & $\begin{array}{c}\text { Last-year } \\
\text { assistant } \\
\mathrm{n}(\%)\end{array}$ & $\mathrm{p}^{*}$ \\
\hline \multicolumn{4}{|c|}{$\begin{array}{l}\text { Institutions responsible for making the medical diagnosis of } \\
\text { occupational disease in Turkey }\end{array}$} \\
\hline Those who know correctly & $24(34.3)$ & $27(39.7)$ & 0.510 \\
\hline Those who misknow & $46(65.7)$ & $4 \mathrm{I}(60.3)$ & \\
\hline \multicolumn{4}{|c|}{ Institution making the legal diagnosis of occupational disease in Turkey } \\
\hline Those who know correctly & $4(5.9)$ & $4(6.0)$ & 1.000 \\
\hline Those who misknow & $64(94.1)$ & $63(94)$ & \\
\hline \multicolumn{4}{|c|}{$\begin{array}{l}\text { The most common occupational disease announced by the official } \\
\text { institutions in Turkey }\end{array}$} \\
\hline Those who know correctly & $24(34.3)$ & $13(19.1)$ & 0.044 \\
\hline Those who misknow & $46(65.7)$ & $55(80.9)$ & \\
\hline \multicolumn{4}{|c|}{ The most common occupational disease worldwide } \\
\hline Those who know correctly & $9(13.0)$ & $5(7.4)$ & 0.272 \\
\hline Those who misknow & $60(87.0)$ & $63(92.6)$ & \\
\hline
\end{tabular}

TABLE 8. Opinions of the participants on the training program to raise awareness of occupational diseases*

\begin{tabular}{lcc|}
$\begin{array}{l}\text { Suggestions for } \\
\text { raising awareness }\end{array}$ & $\begin{array}{c}\text { Yes } \\
\mathbf{n}(\%)\end{array}$ & $\begin{array}{c}\text { No } \\
\mathbf{n}(\%)\end{array}$ \\
\hline $\begin{array}{l}\text { A postgraduate certificate program } \\
\text { related to occupational disease } \\
\text { for raising awareness }\end{array}$ & $15(10.9)$ & $123(89.1)$ \\
$\begin{array}{l}\text { Presence of the occupational disease } \\
\text { department/discipline in universities }\end{array}$ & $34(24.6)$ & $104(75.4)$ \\
for raising awareness & & \\
$\begin{array}{l}\text { Putting on a curriculum related to } \\
\text { occupational disease in the pregraduate } \\
\text { training for raising awareness }\end{array}$ & $54(41.9)$ & $75(58.1)$ \\
$\begin{array}{l}\text { Putting on a specialty-specific } \\
\text { training program related to } \\
\text { occupational disease in the residency } \\
\text { programs for raising awareness }\end{array}$ & $23(16.7)$ & II5 (83.3) \\
\hline $\begin{array}{l}\text { *Numbers and percentages were estimated over the responders of } \\
\text { survey questions }\end{array}$ & \\
\hline
\end{tabular}

of knowledge about the diagnosis, treatment, and notification of OD.

The answers of 47 doctors to the question "What are your opinions and suggestions on the development of Job and Occupational Subspecialist Programs in your country?" were categorized. Four doctors had opinion that the subspecialty program should be included in more specialties in addition to Pulmonary Medicine, Public Health, and Internal Medicine. There were 17 participants who stated that there was no academic basis, and that this subject should be supported and developed.

\section{DISCUSSION}

We determined that during the residency training, the number of physicians who have awareness and knowledge about OD is very low.

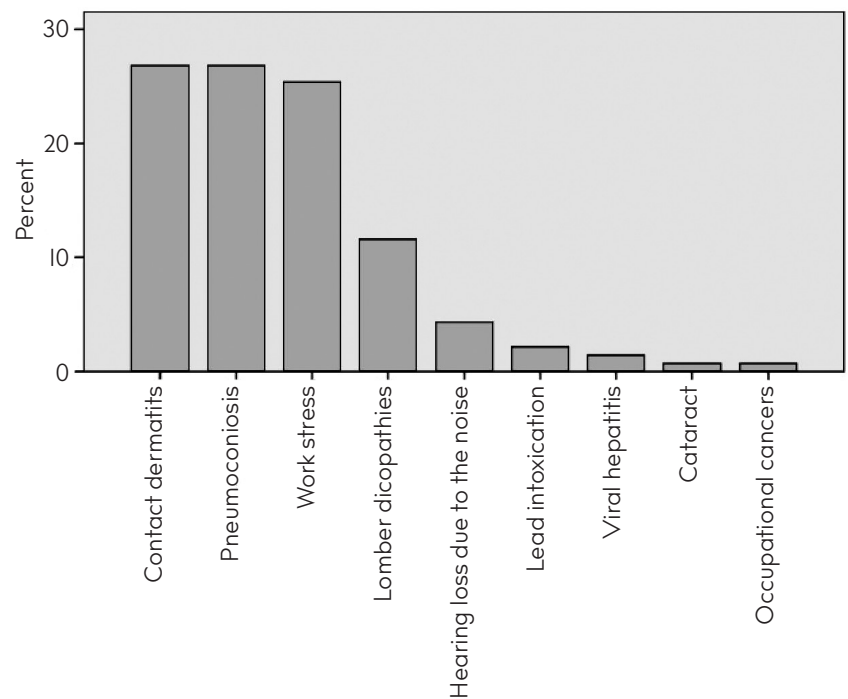

FIGURE I. Distribution of the responses given by participants to the question "What is the most common occupational disease in Turkey according to official registrations?" $(n=139)$

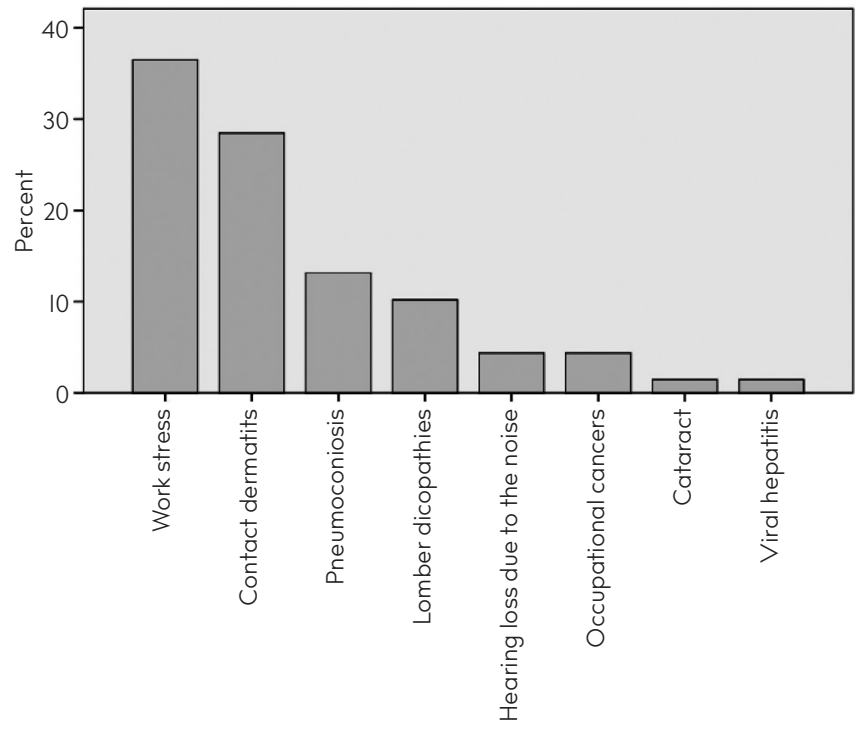

FIGURE 2. Distribution of the responses given by participants to the question "What is the most common occupational disease in the world?" ( $=139)$ 


\section{Providing Continuing Medicine Training in OD}

There is limited research evaluating the knowledge and awareness of physicians about OD during residency training. Previous studies were mostly about testing the level of awareness and knowledge of the recognition of a disease or evaluating the obstacles experienced by clinicians in notifying ODs or detecting pre-graduate education $(4,5)$. To our knowledge, our study is the first study evaluating the awareness of ODs in the residency training period.

Recently, the development of evidence-based medical education is important (6). The striking results of our research will be effective in identifying and improving the deficiencies in ODs in the pre- and postgraduate medical education programs in Ankara University School of Medicine.

We found that the number of physicians who had pregraduate training in ODs was low. Pregraduate training in occupational health and ODs is usually given as a theoretical course by the public health department in the third and fifth grades. Generally, the issues related to ODs are I/I0 of all public health issues. These topics are covered approximately $8 \mathrm{~h} /$ year in the whole training program. Workplace visits are performed in the sixth grade. However, these training and applications are not available in all medical faculties (5). In the United States and in some European countries, occupational medicine training is mandatory during the medical training program, and it is covered within general clinical specialties. The specialties that give training for becoming master and board-certified occupational medicine specialist are the clinics where occupational medicine training is given (7). OD and occupational medicine approaches in other branches are inadequate. In addition, there are very few training programs covering the relationships between environment and occupation in the medical faculties $(8,9)$.

Physicians find themselves insufficient regarding the diagnosis, follow-up, and notification of OD during their residency training in which they are confronted with the patient individually and make their diagnoses, treatments, and follow-ups. Although the continuity of training is very important in the profession of medicine, setbacks in the postgraduate theoretical and practical training of OD lead to inadequacies in residents' attitudes toward diagnosing ODs. However, the role of clinicians, especially that of the attending physicians working in the departments of internal medicine disciplines, is very important in being able to diagnose ODs and in the indirect prevention by making notification (I0).

In Turkey, ODs are not a separate specialty branch. The Occupational Disease subspecialty program has been available in five medical faculties for the last years. It still cannot provide as a specific department. The lack of departments to improve occupational health and ODs medicine causes delays in the identification of cases with these diseases that already face a complex diagnostic process and medicolegal outcomes and even leads to deaths before they can be diagnosed.

\section{Taking Correct Occupational History in Residency Training}

The most important criterion for diagnosing OD is to determine the presence of a relationship between exposure agent and specific disease. For this, it is very important to take detailed occupational history including past exposures $(2,10,11)$. The present study showed that physicians with residency training are aware of the importance of occupational history, but they have insufficient knowledge regarding the need to obtain a detailed occupational history according to chronological order to reach the source of environmental and occupational exposures. Similarly, in a research that was evaluating the knowledge, attitude, and behaviors of practitioners, pulmonologists, and rheumatologists on occupational health and ODs in France, the inquiry about the retrospective occupational exposures of patients by physicians was found to be very low (10). Although the majority of students agreed on the importance of taking occupational history, they considered that physicians did not take occupational history according to the results of a survey conducted on sixth-grade students in Ankara University School of Medicine (5). In some studies, the reasons for the inadequacy of occupational history ranked as the lack of time, lack of knowledge and motivation, and being unaware of the subject $(10,12)$. Although we do not focus primarily on this issue, having insufficient training on $O D$ may have an effect.

According to a previous study conducted in a medical faculty in Ankara University, it was determined that $43.9 \%$ of the physicians did not take any information related to occupation from their patients in the patient records examined (I3). In our study, physicians who took occupational history were low, but there was an increase in last-year residency physicians about following up a patient with an OD and diagnosing OD. This increase may be related to the higher number and variable of patients visited and followed up for 4 years. This may cause changes in the attitudes of last-year research assistants toward taking occupational history.

\section{Attitudes Toward Diagnosing OD and Barriers}

Diagnosis OD is quite a complex process. As in many countries, in Turkey, the legal diagnosis of OD is performed by the SSI following medical diagnosis. It carries the issue to a legal dimension where employee's financial rights are related to compensation. Not only for this responsibility of the physicians but also during the process of proceeding to the step in which treatment is provided with making the correct diagnosis and keeping away from exposure are important. It was determined that physicians generally have a lack of information about their legal responsibilities (14). Physicians during their residency training have inadequate knowledge related to the institutions playing a role in the legal process of ODs. The lack of knowledge in legal responsibilities usually causes poor quality of healthcare services and unwillingness to take legal responsibility (14).

In our study, physicians reported that the most commonly recorded ODs in Turkey were pneumoconiosis and contact dermatitis, followed by work-related stress. They had been thinking that the most common OD worldwide was work-related stress. The most commonly notified and diagnosed OD in Turkey is pneumoconiosis. It is a striking finding that physicians ranked work-related stress among the leading problems in Turkey and worldwide. Data on work-related stress are not clear in Turkey. Although work-related stress and psychological disorders are reported to increase worldwide, they are not ranked in the first three diseases (I5).

Many factors such as deficiencies and difficulties brought about by legal regulations, complexities in reporting and diagnostic system, lack of diagnostic guidelines about $O D$, lack 
of diagnostic standardization for some OD, physicians' knowledge and awareness level of OD, and avoidance of legal difficulties make it difficult to diagnose OD in Turkey as in the world. Physicians self-assessment was showed that the level of the knowledge about the medical and legal diagnostic processes were inadequate in our study. Despite this, it is a contradictory finding that participants did not want to have certification training or other postgraduate training for raising their awareness of diagnosing OD (Table 8). On the contrary, physicians in France suggest that there should be certification programs on OD (I0). In our study, the reason for this contradictory finding may be associated with heavy residency training conditions and more responsibilities placed on physicians in Turkey. In addition, the initiation of a legal process with the diagnosis of OD and the employee confronted with several social problems, such as unemployment, may affect the physicians reducing willingness for being trained and being experienced. Similarly, in a previous study that investigated the barriers to diagnosing occupational asthma by pneumologists in Canada, insufficiency of physicians' awareness and knowledge, limited time allocated for the patient, and the concern that it may cause unemployment were determined as barriers (16).

Since clinicians focus primarily on treating the current disease and clinical manifestations, the patient's workplace conditions can be overlooked, and the avoidance of the exposure in the workplace cannot be ensured even if the relationship between disease and occupation is established (17). We determined that physicians who were having residency training in the internal medicine disciplines do not know that ODs are preventable diseases.

According to the data published by the Ministry of Labor and Social Security in Turkey in 2016, the number of cases in whom ODs were detected was 597, whereas the expected number of cases varied between 40.000 and 120.000 (18). The lack of knowledge and awareness of OD during the pre- and postgraduate training of physicians may be one of the reasons for the lack of these data.

When the association between disease and exposed factor cannot be established, ODs cannot be treated, and they may cause the progression of disease and permanent disability. If the physician skips the index case, it affects the ongoing insufficient hygienic conditions of the workplace indirectly.

The study was conducted on first- and last-year research assistants in the internal medicine disciplines of a single university hospital, and to the best of our knowledge, there was no such study with which we can compare our results with another hospital. Although the fact that we could not generalize our survey results to Turkey is one of the limitations of our study, the lack of any other study evaluating the resident physicians' knowledge of OD makes our study important.

Another limitation of our survey was that we did not include all research assistants including surgical disciplines, and the number of participants was limited.

Since there is no internationally valid scale for the awareness, knowledge, attitude, and behaviors of physicians about OD, using the question form created by us anonymously was another limitation of our study. However, the strong aspects of our study were utilizing the clinical observations of experienced physi- cians of pulmonology and ODs while creating the question form and participation of experienced researchers with public health specialty during the preparation of the questionnaire.

In conclusion, the present study emphasized that the research assistants' levels of awareness and knowledge on OD were low. The decline in the postgraduate training of physicians indicates that training in these fields is interrupted. Postgradvate and residency training programs about OD should be revised to ensure continuing education. All departments of medical sciences should be interested in OD. OD should be managed with multidisciplinary approach. In the short term, it can be possible to establish committees at departments that are frequently encountered with ODs, such as chest diseases, dermatology, and physiotherapy, and these committees can be responsible for the diagnosis, notification, and development of training programs.

Ethics Committee Approval: Ethics committee approval was received for this study from the Ethics Committee of Ankara University School of Medicine. (Approval Date: 23.02.2017, Approval Number: 20 96487027044-E.5469).

Informed Consent: Informed consent was obtained from the patients who participated in this study.

Peer-review: Externally peer-reviewed.

Author contributions: Concept - D.C.., B.Ü.; Design - D.C.., B.Ü.; Supervision - D.C.., M.E.O., B.Ü.; Resource - B.Ü., G.S.; Materials - B.Ü., D.C..; Data Collection and/or Processing - B.Ü., G.S.; Analysis and/or Interpretation - B.Ü., D.C.., M.E.O.; Literature Search - B.Ü., G.S.; Writing - B.Ü., D.C., M.E.O., G.S.; Critical Reviews - B.Ü., D.C.., M.E.O., G.S.

Acknowledgements: Authors thanks to Nazmiye Kursun for data analysis and Dr Levent Özdemir for editing.

Conflict of Interest: The authors have no conflicts of interest to declare.

Financial Disclosure: The authors declared that this study has received no financial support.

\section{REFERENCES}

I. Tadesse T, Admassu M. Lecture for Notes Environmental and Occupational Health and Safety Students. Occupational Health and Safety. Available from: URL: https://www.cartercenter.org/ resources/pdfs/health/ephti/library/lecture-notes/env-occupational-health-students/In-occ-health-safety-final.pdf (cited 2017 May 6).

2. Lax MB, Grant WD, Manetti FA, Klein R. Recognizing occupational disease--taking an effective occupational history. Am Fam Physician 1998; 58: 935-44.

3. Ilıman EZ. Türkiye'de Meslek Hastalıkları. Uluslararası Sağlık Yönetimi ve Stratejileri Araștırma Dergisi 2015; I:I (in Turkish). Available from: URL: http://dergipark.gov.tr/download/article-file/I53587 (cited 2017 May 18).

4. Tsutsumi A, Maruyama T, Nagata M. Psychiatric knowledge and skills required of occupational physicians: priorities in the Japanese setting. J Occup Health 20ll; 53: 37I-6. [CrossRef]

5. Mandıracıoglu A, Batı AH. Ege Üniversitesi Tıp Fakültesi 6. Sınıf Ögrencilerinin Meslek Hastalıkları Egitimi Konusunda Görüslerinin Değerlendirilmesi. Tıp Eğitimi Dünyası 2006; 21 (in Turkish). Available from: URL: http://dergipark.ulakbim.gov.tr/ted/article/ view/500014039l (cited 2017 May 2).

6. Masoomi R. What Is the Best Evidence Medical Education. Research and Development in Medical Education. 2012; I: 3-5. Available from: 
URL: http://journals.tbzmed.ac.ir/RDME/Manuscript/RDME-I-3. pdf (cited 2017 July 19).

7. Lane DS. A threat to the public health workforce: evidence from trends in preventive medicine certification and training. Am J Prev Med 2000; 18: 87-96. [CrossRef]

8. Burstein JM, Levy BS. The teaching of occupational health in US medical schools: little improvement in 9 years. Am J Public Health 1994; 84: 846-9. [CrossRef]

9. Schenk M, Popp SM, Neale AV, Demers RY. Environmental medicine content in medical school curricula. Acad Med 1996; 71: 499-50I. [CrossRef]

10. Arnaud S, Cabut S, Viau A, Souville M, Verger P. Different reporting patterns for occupational diseases among physicians: a study of French general practitioners, pulmonologists and rheumatologists. Int Arch Occup Environ Health 2010; 83: 25I-8. [CrossRef]

II. Felton J. The occupational history: A neglected area in the clinical history. J Fam Pract 1980; II: 33-9.

12. Harber P, Mullin M, Merz B, Tarazi M. Frequency of occupational health concerns in general clinics. J Occup Environ Med 200I; 43: 939-45. [CrossRef]
13. Çımrın AH, Sevinc C, Kundak I, Ellidokuz H, Itil O. Attitudes of medical faculty physicians about taking occupational history. Med Educ 1999; 33: 466-7. [CrossRef]

14. Zajdel J, Zajdel R, Kuna P. Knowledge of medical law amongst doctors of internal diseases. Int J Occup Med Environ Health 2013; 26: 242-56. [CrossRef]

15. Workplace stress: A collective challenge International Labour Organization 20l6. Available From: URL: http://wwwilo.org/wcmsp5/groups/public/---ed_protect/---protrav/---safework/documents/publication/wcms_473267.pdf (cited 2017 May 20).

16. Parhar A, Lemiere C, Beach JR. Barriers to the recognition and reporting of occupational asthma by Canadian pulmonologists. Can Respir J 20II; 18: 90-6. [CrossRef]

17. Harber P, Merz B. Time and knowledge barriers to recognizing occupational disease. J Occup Environ Med 200l; 43: 285-8. [CrossRef]

18. Meslek Hastalıkları Rehberi. Çalıșma ve Sosyal Güvenlik Bakanlığı, Ankara, 20ll. (in Turkish). Available From: URL: http://www3.csgb. gov.tr/csgbPortal/ShowProperty/WLP\%20Repository/isggm/dosyalar/Meslek-Hastaliklari-Kitab\%C4\%BI (cited 2017 May 2). 